\title{
Sağlık Çalışanlarının Kariyer Yönetimi Kapsamında Eğitim ve Geliştirme Faaliyetlerine Yönelik Algılarının İş Tatmini Üzerindeki Etkisinin İncelenmesi
}

\section{Investigation of The Effects of Health Employees' Perfections on Training and Development Activities on Job Satisfaction in Career Management}

Erhan Kılınç a,*

a Selçuk Üniversitesi, Beyşehir Ali Akkanat İşletme Fakültesi, Uluslararası Ticaret ve İşletmecilik Bölümü, Konya/ Türkiye. ORCID: 0000-0002-2065-2407

\section{MAKALE BİLGİSI}

\section{Makale Geçmişi:}

Başvuru tarihi: 22 Eylül 2019

Düzeltme tarihi: 19 Ocak 2019

Kabul tarihi: 29 Subat 2020

\section{Anahtar Kelimeler:}

Kariyer yönetimi

Eğitim ve geliştirme

İş tatmini
ÖZ

Kariyer bireylerin iș ve eğitim hayatında yer aldığı konumlar ve pozisyonlar anlamına gelmektedir. İşletmelerde eğitim ve geliştirme faaliyetlerinin kariyer yönetimi kapsamında yeri son derece önemlidir. Bu faaliyetlerin çalışan beklentileri ve örgütsel amaçlar doğrultusunda planlanması ve yürütülmesi, iş tatmini üzerinde olumlu katkı sağlayacağı düşünülmektedir. Bu çalışmanın amacı, kariyer yönetimi kapsamında uygulanan eğitim ve geliştirme faaliyetlerinin iş tatmini üzerindeki etkisinin incelenmesidir. Bu kapsamda Antalya ilinde faaliyet gösteren özel ve kamu sağlik kuruluşlarında görev yapan toplam 255 sağlık çalışanına anket uygulanmıştır. Araştırma sonucunda, sağlık çalışanların kariyer yönetimi kapsamında eğitim ve geliştirme algıları ile iş tatmini arasında orta düzey pozitif bir ilişkinin olduğu; eğitim ve geliştirme faaliyetlerinin çalışanların memnuniyeti üzerinde olumlu etkilediği ve eğitim ve geliştirme faaliyetlerinin iş tatminin \%46,4'lük kısmını açıkladığı saptanmıştır.

\section{A R T I CLE INFO}

\section{Article history:}

Received 22 September 2019

Received in revised form 19 January 2020

Accepted 29 February 2020

\section{Keywords:}

Career management

Training and development

Employee satisfaction

\begin{abstract}
A B S T R ACT
Career means positions where individuals are involved in business and education life. The place of training and development activities within the scope of career management is very important. It is thought that planning and conducting these activities in line with employee expectations and organizational objectives will contribute positively to job satisfaction. The purpose of this study is to investigate the effect of training and development activities implemented within the scope of career management on job satisfaction. In this context, a survey was applied to a total of 255 healthcare professionals working in private and public health institutions at Antalya. As a result of the research, there is a moderate positive relationship between the perception of education and development of health workers within the scope of career management and job satisfaction; It was found that training and development activities had a positive effect on job satisfaction and training and development activities explained $46.4 \%$ of job satisfaction.
\end{abstract}

\section{Giriş}

Günümüzde işletmelerin karşılaştı̆ğ en büyük zorluklardan birisi, insan kaynağı yeteneklerinin ve kişisel gelişimlerinin etkili yönetilmesi sorunudur. İşletmeler, bu sorunu çözebilmek için iyi planlanmış bir eğitim ve gelişim programını ihtiyaç duyarlar. Ayrıca planlanan eğitim ve gelişim programlarının verimli, düşük maliyetli, çalışanların beklentilerini karşılayan ve değişen diş gereksinimlere uyumlu olması da dikkat edilmesi gereken hususlardandır.
Diğer taraftan, bir insanın hayatında verilen en önemli kararlarından birisi kariyer yolunu çizmek ve kariyer haritasını belirlemektir. Yaşamı boyunca çeşitli fiziksel, duygusal ve sosyal değişimlere maruz kalan birey, çeşitli etkilerin altında kariyer tercihi yapmaktadır. Kariyer, genel olarak, bireyin hayatı boyunca yaptığı işlerde ve çalıştığı işyerlerinde yer aldığı konumlar veya pozisyonlar anlamına gelmektedir. Kariyer, bireyin toplum içinde sosyal statüsünü belirleyen, onu meşgul eden, maddi olarak hayatını kazanmasını sağlayan ve kendini gerçekleştirme amacına

* Sorumlu yazar/Corresponding author.

e-posta: erhankilinc@selcuk.edu.tr 
ulaşmasını sağlayan yol gösterici ve harekete geçirici bir güçtür.

Kariyer kavramının içerisinde en önemli faktörlerden ve araçlardan biri ise eğitim ve geliştirme faaliyetleridir. Eğitim ve geliştirme faaliyetlerin doğru ve sağlıklı bir biçimde planlanması ve yürütülmesinin çalışanların memnuniyeti üzerinde olumlu etkisi olacağı düşünülmektedir. Bununla birlikte iş memnuniyeti üzerine yapılan birçok araştırma, genel iş memnuniyetinin bir unsuru olan işyeri eğitiminin memnuniyeti üzerinde yeterince durulmadığını da ortaya koymaktadır (Schmidt, 2009: 297).

$\mathrm{Bu}$ çalışma sağlık çalışanlarının kariyer yönetimi bağlamında eğitim ve geliştirme faaliyetlerine karşı algılarının onların memnuniyet düzeyi açısından etkisini belirlemek için yapılmıştır. $\mathrm{Bu}$ kapsamda sağlık çalışanlarının demografik değişkenleri açısından eğitim ve geliştirme faaliyetlerine yönelik algılarının iş tatmininde farklılık gösterip göstermediği de ortaya konmaya çalışılmıştır. Bu araştırma ile "Sağlık çalışanlarının kariyer yönetimi kapsamında eğitim ve geliştirme faaliyetlerine yönelik algılarının iş tatmini üzerindeki etkisi nedir?" sorusuna yanıt aranmaya çalışılmıştır.

Çalışmada, öncelikle kariyer, eğitim ve geliştirme ve iş tatmini kavramları açıklanmış, bu kavramların insan kaynakları yönetimi, çalışanlar ve örgütler açısından önemi vurgulanmıştır. Araştırmanın devamında, Antalya ilinde faaliyet gösteren ikisi özel, ikisi kamu olmak üzere dört hastanede görev yapan sağlık çalışanları üzerinde yapılan anket çalışması sonuçları sunulmuştur. Son bölümde araştırma sonucu ve önerilere yer verilmiştir.

\section{Literatür Özeti}

\subsection{Kariyer ve Kariyer Yönetimi}

Günümüz iş dünyasında yaşanan değişim ve gelişmeler, örgütleri birçok yönden etkilemiştir (Şimşek vd., 2016:127128). Artık işletmeler, toplumun ihtiyaç duyduğu mal ve hizmetleri üretebilmeleri için gelişmiş teknoloji ve nitelikli işgücüne daha çok ihtiyaç duyar hale gelmişlerdir (Geylan, 2004: 99). Bunun bir nedeni, işletmelerin başarı veya başarısızlığının insan kaynağının kalitesi ile bağlantılı olmasıdır (Abdulraheem Salah, 2016: 36). Bilindiği üzere, emek-yoğun işletmelerden üretimde yüksek ve ileri teknoloji kullanan işletmelere kadar birçok işletmenin başarısı, insan kaynağının ve onun başarısının bir ürünüdür. Özellikle nitelikli personelin örgütlere olan katkısı yadsınamaz bir gerçektir (Uyargil vd., 2013: 103).

Diğer taraftan, insan kaynağının başarılı ve verimli olması için onların işinden ve işyerinde memnun olması gereklidir (Şimşek vd., 2016:127-128). Bu nedenle çalışanlarının örgütten beklentileri, istekleri ve çalışma ilişkileri önemli hale gelmiştir (Uyargil vd., 2013: 103). Artık, işletmelerin işgücünden istediği verimi alabilmeleri için onlara gerekli değeri ve önemi göstermeleri gerekmektedir (Geylan, 2004: 99). Eğer bu sağlanmazsa, artık nitelikli ve deneyimli iş gücünü bulup işletmeye almak ve onları işletmede tutmak ciddi bir sorun haline gelecektir. Nitelikli işgücünü işletmede tutulabilmenin yollarından biri, gelişmeye açık bir kariyer yönetim sistemini kurmaktır. Artık işletmeler, çalışanları için kayda değer düzeyde kariyer programları ve uygulamaları düzenlemelidirler (Soysal ve Kılınç, 2016: $331)$.
Geçmişi 16.yüzyıla dayanan ve iş dünyasında 1970 yılların başlarından itibaren yoğun olarak kullanılmaya başlayan kariyer kavramı, gelişimi ve insan yaşamı üzerindeki etkisi ile araştırmacıların dikkatini çekmiş ve ilgi noktası haline gelmiştir (Şimşek, vd., 2004: 4-5). Günümüz iş dünyasında çalışanlar arasında rekabetin artması, firsatları değerlendirme ve çalışanların refah içinde daha iyi bir hayat yaşama arzusunun yaygınlaşması gibi gelişmeler, bireyci yaklaşımlarda bir artışa neden olmuştur. Bu durum işletme çalışanlarının iş değiştirme ve farklı mesleklere geçme imkânlarını artırmış ve kariyer kavramının daha da önem kazanmasına neden olmuştur (Şimşek vd., 2016: 129).

Bununla birlikte, işyerinde örgütsel ve teknik değişim karşısında kariyer gelişiminin doğasına ilişkin varsayımlar, bireylerin artık iş güvencesi kapsamında yaşam boyu istihdam görmeleri daha az olası olduğunu ve bunun yerine dinamik bir kariyer süreciyle karşı karşıya kaldıklarını ortaya koymaktadır. $\mathrm{Bu}$ nedenle bireyler, kariyerlerini etkin bir şekilde yönetme konusunda daha yetenekli ve istekli hale gelmişlerdir (Ball ve Jordan, 1997: 507).

Kariyer, "bireyin, başlangıç yaptığı, yaşamının üretken yıllarını kullanarak geliştirdiği ve genelde çalışma hayatının sonuna dek sürdürdüğü iş ya da pozisyon" olarak tanımlanabilir (Anadolu Sözlük, 2019). Kariyer, kişinin çalışma hayatında, işe ilişkin bilgi düzeyi, deneyimi, aktivitesi ve hiyerarşik pozisyonunu gösteren bir bileşke anlamina gelmektedir. Bireyler belirli bir pozisyonda faydalı deneyimler ve başarılar elde ederler, daha sonra kendilerini ve işlerini geliştirerek daha üste bir pozisyona geçerler (Soysal ve Kılınç, 2016: 331).

Kariyer kısaca bireyin hayatı boyunca çalıştığı işlerde yer aldığ onun toplum içinde sosyal statüsünü belirleyen, ona kendini gerçekleştirme imkânı sunan ve dolayısıyla maddi kazançlar elde etmesini sağlayan ve ona yol gösteren bir itici güçtür (Bayraktaroğlu, 2006: 137; Kozak, 2001: 17).

Kariyer gelişimi, bireylerin kariyerlerini etkileyen şans faktörleri ile birlikte psikolojik, sosyolojik, eğitimsel, ekonomik ve fiziksel faktörleri kapsayan yaşam boyu devam eden bir süreçtir (Brown, 2002: 14). Değişen iş sözleşmeleri, işgören haklarının iyileştirilmesi noktasında yapılan hukuki gelişmeler ve öğrenen organizasyon yapılarının yaygınlaşması ile birlikte çalışanların devir hızının azaltılması, verimliliğin artırılması ve gerçek dışı beklentiler konusunda işgörenlerle uzlaşma sağlanması için işletmelerin çalışanlarının kariyer gelişimine daha fazla önem vermeleri gerekmektedir (Şimşek vd., 2016: 253).

Kariyer yönetimi faaliyetleri, çalışanların yetenek ve ilgi alanları ile işletmenin gereksinimleri kapsamında kariyer ilerletme faaliyetlerinin planlaması ve yürütülmesi çabalarıdır (Uyargil vd., 2013: 309). Kariyer yönetimi süreci ise kariyer araştırması, kariyer hedeflerinin geliştirilmesi ve kariyer hedeflerine ulaşmak için kariyer stratejilerinin kullanılması aşamalarını içermektedir (Noe, 1996:119).

Çoğu insan kariyer yönetimi ve gelişiminin sadece iş becerisi ve eğitimi anlamına geldiğine inanmaktadır. Onlara göre, çalışanların kişisel gelişimlerinin kariyerleriyle ilgisi yoktur. Oysa iş becerileri ve eğitim işgörenleri sadece kariyerine kadar götürür. İşgöreni başarıya ulaştırması için ise bazı tutum, inanç ve davranışlara ihtiyaç vardır. Bu noktada kişisel gelişim, kariyer başarısının kritik bir anahtarıdır. 
Kişisel gelişim, işgörenlerin farkındalığını, kimliğini, yeteneklerini ve potansiyelini geliştiren ve insan sermayesini inşa eden faaliyetlerdir (Universal Class, 2019).

\subsection{Eğitim ve Geliştirme}

Eğitim, bireyin hayat boyu devam eden bir bilgilendirme ve bilgi, beceri ve davranışlarında meydana gelen bir değişim süreci ve gelişim sürecidir (Fındıkçı, 2018: 229). Diğer bir tanımda eğitim, bireyin bilgi, beceri ve davranışlarında kalıcı değişiklikler yaratma sürecidir (Geylan, 2004: 97). Genel anlamda eğitimin en temel özelliği, birey, firma ve toplumun geleceklerine yatırım yapmasıdır (Özsoy,2007: 42-47).

Eğitim, insan sermayesine, yani bireye daha yüksek kazanç şeklinde bir geri dönüş sağlayan bilgi ve beceriye yapılan bir yatırımdır. Bu anlamda eğitim için yapılan yatırımların gereksiz görülmesi oldukça yanlıştır. Ekonomistler, eğitime harcanan yatırımların geri dönüşünün her eğitim seviyesi için istikrarlı bir şekilde arttığını ileri sürmüşlerdir. Eğitimin sosyal getirileri veya yayılmaları da vardır. Eğitim, insanların kazanma yeteneklerini artıran bilgi ve becerilere yapılan bir yatırımdır (Nadeak ve Purba, 2014: 2; Geylan, 2004: 99; Fındıkçı, 2018: 225-226).

Bilgi çağının başlaması ile birlikte toplumun eğitim ve gelişmeye olan ihtiyacı günden güne artmıştır (Geylan, 2004: 97; Fındıkç1, 2018: 225). Sanayileşme ile birlikte ulus devletlerin doğuşundan beri eğitim; toplumu ve insanları şekillendiren, ekonomik ve sosyal kalkınmayı sağlayan bir güç ve araç olarak görülmüştür. Yetişmiş insan gücüne sahip olan toplumların, gelişmiş toplumlar olduğundan, eğitim insana ve ülkenin geleceğine yapılmış en önemli ve en karlı yatırım aracı olarak görülür (Ergün,2011: 1).

Eğitim ekonomik anlamda, büyüme, gelişme, rekabet gücü ve verimlilik artışı, sosyal anlamda ise; katılımcılık, sosyal uyum, çevre koruma gibi politika alanların merkezinde yer almaktadır (Özsoy,2007: 42-47). Bir ülkenin kalkınıp ilerlemesinde temel dinamiklerden biri eğitimdir. Eğitim bir itici güçtür ülke ekonomisini destekler ve istenilen kalkınma düzeyine ulaşılmasına katkı sağlar (Yapıcı, 2003:1; Bayrakdar, 2011: 254; Altınışık ve Peker,2012:1). Eğitim, makro düzeyde ekonomik ve sosyal boyutlarıyla ekonomik kalkınmanın en önemli kaynaklarındandır (Özsoy,2007: 4247). Diğer taraftan günümüz iş dünyasının en önemli unsuru yetişmiş ve nitelikli işgücüdür ve bu, kapital, teknolojik makine veya sistemlerden önce gelmektedir (Tunçalp, 2013:3).

Eğitim ve gelişim, çalışanlarının performanslarını çeşitli eğitim yöntemleri ve programlarıyla geliştirmek için organizasyonlar içinde yürütülen resmi ve devam eden çabalardır. Modern işyerlerinde bu çabalar, oldukça spesifik iş becerilerindeki eğitimlerden uzun vadeli mesleki gelişime kadar geniş bir uygulama yelpazesinde uygulanmaktadır (Inc., 2019).

Çoğunlukla, "eğitim" ve "gelişim" terimleri, bir kuruluş çalışanlarının genel gelişimini ve eğitimini tanımlamak için birlikte kullanılmaktadır. Bununla birlikte, bu terimler arasında önemli farklılıklar vardır. Genel olarak, eğitim programlarının belirli bir makine parçasını çalıştırmak, belirli bir işlemi anlamak veya belirli işlemleri büyük bir hassasiyetle gerçekleştirmek gibi çok özel ve ölçülebilir hedefleri vardır. Diğer taraftan gelişim programları karar verme, liderlik becerileri ve hedef belirleme gibi daha geniş kapsamlı durumlara uygulanabilir daha geniş becerilere odaklanmaktadır (Inc., 2019). Eğitim, çalışanların mevcut rollerinde performansı artırmak için belirli bilgi veya becerileri öğrenmelerine yardımcı olan bir programdır. Gelişme ise daha geniştir ve acil bir iş rolünden ziyade, çalışanların büyümesine ve gelecekteki performansına odaklanır (Allencomm, 2019).

İnsan kaynaklarının yetenek eksikliği ve entelektüel yetenekleri ile ilgili temel konuların çalışanların eğitim ve teknik eğitim düzeylerine dayandığı ileri sürülmektedir (Low, 1998). İşletmelerde zaman geçtikçe ve meslekte ilerledikçe yeni beceri ve bilgilere ihtiyaç duyulmaktadır. Genelde çalışanların gelecekteki kariyerleri ile ilgili gelişme ve ilerleme isteği, onların dinamik bir yapı kazanmalarında son derece önemli bir olgudur (Erdil ve Öztutku, 2013: 2017). İşgören geliştirme, performans değerlendirmenin sonucunda ortaya çıkan eksikliğin giderilmesi için yapılan planlanma ve uygulama çalışmalarıdır (Erdil ve Öztutku, 2013: 49).

İşyerlerinde eğitim, çalışanın işe başlamasından işten ayrılışına kadar süren uzun bir süreçtir. İşyerinde eğitimin çıktısı, daha bilgili, daha becerikli ve nitelikli personeldir. Çalışanlarını eğiten işletmeler, daha yetenekli ve verimli çalışanları sahip olurlar. İşyerinde eğitimle işletmeler, çalışan verimliliği ve memnuniyeti ile işletme performansını yükseltmeyi hedeflemektedir. (Geylan, 2004, 101).

Ayrıca, işyerinde eğitim ve geliştirme, ulaşılacak bir sonucun ötesinde çalışanların beklentilerinin karşılanmasında ve örgütün stratejik amaçlarının geçekleștirilmesinde önemli bir araçtır (Öge, 2016: 249). İşletmelerde eğitimler kurgulanırken örgütsel ve bireysel amaçlar ve ihtiyaçlar sentezlenerek en çok katkı sağlayacak ve kabul görecek bir model oluşturulmalıdır (Öge, 2016: 260). Ayrıca işletmelerde eğitimin amacı değişim ve dönüşümlere karşı daha hızlı uyum sağlama yeteneğini sağlamaktır. Buradaki eğitimle öğrenmeyi sürekli kılmak ve çalışanlara öğrenmeyi öğretmek amaçlanmalıdır (Fındıkçı, 2018: 226).

Örgütlerde eğitimin belli başlı temel amaçları vardır. Bunlar; işe yeni başlayanların uyumunu (oryantasyonunu) sağlamak, çalışanlara yeni beceriler kazandırmak, çalışanlara daha fazla güven kazandırmak, çalışanların eski becerilerini canlandırmak, başarı düzeyini devam ettirmek, teknolojik değişimlere uyum sağlamak, personel devir hızını düşürmek ve iş tatminini sağlamak gelmektedir (Geylan, 2004: 101; Your Training Edge, 2019). Örgütlerde eğitim ihtiyacı işgörenlerin performans düzeylerindeki yetersizlikler ve standartların altında kalmasında, değişen iç ve dış çevre koşullarına uyum sağlamak gerektiğinde ve işgörenlerin görev değişimi veya ek görevler almaları durumunda ortaya çıkmaktadır (Barutçugil, 2004: 299). Buradan yola çıkarak örgütsel ihtiyaçlar, mesleki ihtiyaçlar ve kişisel ihtiyaçlar eğitimin sürekli olmasını gerektiren durumlardır (Barutçugil, 2004: 299).

Çalışanların kariyer seçimlerine ilişkin kararlarda eğitim ve gelişim firsatları oldukça önemlidir (Schmidt, 2009: 297). Çalışanların kariyerleri açısından eğitim yollu edinilen bilgi, beceri ve yeteneklerin düzeyi onun firsatları yakalamasında, kendini gerçekleştirmesinde, maaş, yükselme ve gelişme anlamında önemli bir faktördür. Çalışanların eğitim alabilmeleri veya eğitimlerine zaman ayırabilmeleri 
konusunda yaşanacak olumlu gelişmeler, çalışanların daha çok motive olmasına, daha yüksek bir iş tatmini yaşamasına ve işletme hakkında olumlu düşüncelere sahip olmasına katk1 sağlayacağ1 söylenebilir (Şimşek vd., 2016:270). İşletmelerde eğitim ile çalışanların iş tatmini, verimliliği, iletişimi ve örgütsel performansı artırmak mümkündür. Bu anlamda eğitim sadece çalışan için değil örgütsel hedefler için de büyük fayda sağlar (Geylan, 2004: 101).

\section{3. İş Tatmini}

İnsan hayatının büyük bir kısmı, ișyerlerin iş ve meslekle ilgili faaliyetlerle geçmektedir. $\mathrm{Bu}$ nedenle bireylerin mutluluğu ve refahı açısından iş tatmini önemli bir olgudur. Bir işyerinin başarısı, çalışanların yaşam kalitesinin artırılması ve fizyolojik, psikolojik, sosyolojik ve ekonomik ihtiyaçlarının karşılanması ile mümkündür. Wroom'un beklenti teorisine göre insanlar ihtiyaçlarını tatmin etmek için davranışta bulunurlar. $O$ yüzden onları kendi ihtiyaçlarını karşılayacakları örgütsel amaçlara yönlendirmek doğru olacaktır (Izgar, 2012: 97-99).

İş tatmini olgusu, bireylerin hayatını kişisel, sosyal ve duygusal olarak pozitif yönde etkileyen ve gözlemlenebilen iç zevk ve huzurun dışa vurumu olarak tanımlanmaktadır (Keser, 2012: 4). İş tatmini, işgörenin işyerinden elde ettiği maddi kazanç, iş güvenliği, işyeri koşulları ve imkanları, işinin keyif verme yönü, işinden gurur duyma, bireysel gelişim, terfi imkanları ve olumlu insani ilişkiler gibi kavramlarla ilişkilidir (Şimşek vd., 2015: 164).

Eğitim ve geliştirme ile iş tatmini arasındaki ilişkiyi araştıran çalışmalar incelendiğinde aşağıdaki sonuçlara ulaşıldığı görülmektedir.

- Şener (2009) tarafindan eğitim sektöründe yapılan çalışmada, hizmet içi eğitimin öğretmenlerin mesleki motivasyon düzeylerine olumlu bir etkisi olduğu saptanmıştır.

- Schmidt (2009: 297) yaptığı çalışmada, iş eğitimi memnuniyeti ile genel iş memnuniyeti arasında anlamlı bir ilişki saptamıştır.

- Aslan tarafindan (2012) otomotiv sektöründe bir şirketin kariyer yönetiminin incelediği çalışmada, çalışanların kariyerlerinin eğitimle desteklenmesi, hem işletme hem de çalışanlar açısından anlamlı ve başarılı sonuçlara katkı sağladığı sonucuna ulaşılmıştır (Arslan, 2012: 83).

- Jaiswal ve Chandra (2014) tarafindan Hindistan'da 170 işletme çalışanı üzerinde yapılan araştırmada, eğitim ve geliştirme faaliyetlerinin örgütlerde iş tatminini artırdığını göstermektedir (Jaiswal ve Chandra, 2014: 24-39).

- Quizon (2014) tarafindan özel bir firmada yapılan çalışmada, eğitim düzeyi ne olursa olsun çalışanların daha fazla eğitim almak istediği sonucuna ulaşılmıştır (Quizon, 2014: 45-53).

- Armağan (2015) tarafından liselerde yapılan çalışmada eğitim ve geliştirme faaliyetlerinin iş tatminini olumlu etkilediği ortaya konmuştur (Armağan, 2015: 305).

Kariyer, iş tatmininin önemli bir nedenidir. İşverenler ve yöneticiler tüm işletme çalışanlarını kapsayacak bir kariyer politikası belirlemeli ve özellikle işletmede yükselme şansı olduğunu çalışanlarına göstermelidir. Ayrıca istikrarlı bir çekirdek işgücü korumak için çalışanlara kariyer firsatları sağlanmalı ve planlanmalıdır (Armstrong, 2008:165). Sonuç olarak, yapılan literatür çalışmaları hangi sektör ya da iş alanı olursa olsun eğitim geliştirme faaliyetlerinin iş tatmini üzerinde etkili olduğu göstermektedir. Bu nedenle kariyer yönetimi kapsamında uygulanan eğitim ve geliştirme faaliyetlerinin hem örgütsel hem de çalışan açısından karşılıklı ve kazan- kazan ilişkisi temeline dayalı olması sonucu ortaya çıkartmaktadır (Kahraman ve Fındıklı, 2018: 88).

\section{Yöntem}

\subsection{Araștırmanın Amacı}

$\mathrm{Bu}$ çalışma sağlık çalışanlarının kariyer yönetimi bağlamında eğitim ve geliştirme faaliyetlerine karşı algılarının onların memnuniyet düzeyi açısından etkisini belirlemek için yapılmıştır. $\mathrm{Bu}$ kapsamda sağlık çalışanlarının demografik değişkenleri açısından eğitim ve geliştirme faaliyetlerine yönelik algılarının iş tatmininde farklılık gösterip göstermediği de ortaya konmaya çalışılmıştır.

\subsection{Araştırma Hipotezleri}

$\mathrm{H}_{1}$ : Sağlık çalışanlarının eğitim ve geliştirme faaliyetlerine yönelik algıları ile iş tatmini arasında pozitif ve anlamlı bir ilişki vardır.

$\mathrm{H}_{2}$ : Sağlık çalışanlarının eğitim ve geliştirme faaliyetlerine yönelik algıları demografik değişkenlere göre anlamlı bir farklılık gösterir.

$\mathrm{H}_{3}$ : Sağlık çalışanlarının iş tatmin düzeyleri demografik değişkenlere göre anlamlı bir farklılık gösterir.

\subsection{Tasarım ve Veri Toplama Yöntemleri}

Bu çalışma, tanımlayıcı ve kesitsel bir araştırmadır. Antalya ilinde 4'ü kamu 13'ü özel olmak üzere toplamda 17 hastane bulunmaktadır. Araştırma kapsamında Antalya ilinde faaliyet gösteren 2'si özel sektör, 2'si kamu olmak üzere toplam 4 hastane araştırmanın evrenini oluşturmuştur.

Bu hastanelerde görev yapan toplam çalışan sayısı, 1450'dir. Araştırmaya katılmaya gönüllü olan ve kolayda örnekleme yöntemi ile seçilmiş toplam 255 sağlık çalışanına anket uygulanmıştır. $\mathrm{Bu}$ sayı, ana kütlenin \%17,58'ini temsil etmektedir. Ana kütlenin 1450 kişiden oluşumu, $\% 90$ güven seviyesinde formüle edildiğinde, 229 adet denek ile anket yapılmasının yeterli olduğu sonucu ortaya çıkmaktadır (Weiers, 2008: 300). Veriler 2019 yılı Ocak-Şubat ayları içerisinde toplanmıştır.

Anket formu, 7'si sosyo-demografik soru olmak üzere, 6 faktör (Algılanan Eğitim Olanakları, Algılanan Amir Desteği, Algılanan Çalışma Arkadaşları Desteği, Öğrenme Motivasyonu, Bireysel Kazançlar, Kariyer Beklentileri) ve 29 sorudan oluşan "Eğitim ve Geliştirme Ölçeği” ile 20 sorudan oluşan "İş Doyum Ölçeği” olmak üzere toplam 56 sorudan oluşmaktadır.

Eğitim ve Geliştirme Ölçeği ve İş Tatmini ölçekleri 5'li Likert şeklinde düzenlenmiştir. Kesinlikle katılıyorum (5), katılıyorum (4), Ne katıliyorum ne de katılmiyorum (3), katılmıyorum (2), kesinlikle katılmıyorum (1) olarak puanlanmıştır. İki ölçekte de ortalamanın yüksek olması, eğitim ve geliştirme düzeyinin ve iş tatmini düzeyini yüksek olduğunu göstermektedir. 
Araştırmada kullanılan eğitim ve geliştirme ölçeği, Kahraman ve Fındıklı tarafindan (2017) İstanbul'da sanayi, hizmet, ticaret ve inşaat sektörü çalışanları üzerinde yapılan çalışmadan alınmıştır. Bu çalışma da ölçeklerin geçerlilik ve güvenirlilikleri yüksek bulunmuştur. İş Tatmini Ölçeği olarak, Minnesota İş Doyum Ölçeği kullanılmıştır.

\subsection{Veri Analizi}

Araştırma verileri SPSS paket programında değerlendirilmiştir. Veriler, Student T testi (iki ortalama arasındaki farkın önemliliğinin sınanması), ANOVA, Pearson korelasyon analizi ve regresyon analizi testleri ile yorumlanmıştır.

\subsection{Geçerlilik ve Güvenirlilik}

Anketin güvenirliği, iç tutarlılık katsayıları değerlendirilerek her ölçek ve alt boyutlar için ayrıca hesaplanmıştır.

\begin{tabular}{|c|c|}
\hline Ölçekler ve Boyutlart & $\begin{array}{l}\text { Cronbach Alpha } \\
(\alpha)\end{array}$ \\
\hline Ĕgitim ve Geliştirme Ölçeği & $\mathbf{0 , 8 2 6}$ \\
\hline Öğrenme Motivasyonu & 0,854 \\
\hline Bireysel Kazançlar & 0,865 \\
\hline Algllanan Amir Desteği & 0,881 \\
\hline Algılanan Çalışma Arkadaşları Desteği & 0,843 \\
\hline Algılanan Eğitim Olanakları & 0,851 \\
\hline Kariyer Beklentileri & 0,857 \\
\hline İş Tatmini & 0,848 \\
\hline
\end{tabular}

Tablo 1: Araştırma Ölçeklerinin ve Faktörlerinin Güvenirlik Sonuçları

Alpar (2000)'a göre anketin güvenilirliğinin test edilmesinde kullanılan Cronbach Alfa güvenilirlik katsayısı 60-79 arasında olduğunda oldukça güvenilir, 80-100 arasında olduğunda ise ölçek yüksek güvenilirlikte kabul edilmektedir. Yapılan AFA da ölçek maddelerinin orjinaline uygun dağılım gösterdiği ve faktör yüklerinin yeterli düzeyde olduğu görüldüğünden kullanılan ölçekler geçerli kabul edilmiştir.

\section{Bulgular ve Yorumlar}

Araştırma anketlerinden elde edilen bulgular aşağıda verilmiştir.

Tablo 2- Katılımcıların Sosyo-Demografik Özelliklere Göre Dağılımı

\begin{tabular}{|c|c|c|c|}
\hline \multicolumn{2}{|l|}{ Değişkenler } & $\begin{array}{c}\text { Sayı } \\
\text { (n) }\end{array}$ & $\begin{array}{c}\text { Yüzde } \\
(\%)\end{array}$ \\
\hline \multirow[t]{2}{*}{ Hastane türü } & Özel hastane & 105 & 41,2 \\
\hline & Kamu hastanesi & 150 & 58,8 \\
\hline \multirow[t]{2}{*}{ Cinsiyet } & Kadın & 166 & 65,1 \\
\hline & Erkek & 89 & 34,9 \\
\hline
\end{tabular}

\begin{tabular}{|c|c|c|c|}
\hline \multirow[t]{2}{*}{ Medeni durum } & Evli & 137 & 53,7 \\
\hline & Bekar & 118 & 46,3 \\
\hline \multirow[t]{3}{*}{ Eğitim durumu } & Lise & 90 & 35,3 \\
\hline & Üniversite & 131 & 51,4 \\
\hline & Lisansüstü & 34 & 13,3 \\
\hline \multirow[t]{4}{*}{ Meslek } & Hekim & 21 & 8,2 \\
\hline & Hemşire & 57 & 22,4 \\
\hline & $\begin{array}{l}\text { Sağlık teknisyeni/ } \\
\text { teknikeri }\end{array}$ & 29 & 11,4 \\
\hline & $\begin{array}{l}\text { Tibbi Sekreter/ Hasta } \\
\text { danışmanı }\end{array}$ & 148 & 58,0 \\
\hline \multirow[t]{3}{*}{ Yaş durumu } & $20-30$ & 125 & 49,0 \\
\hline & $31-40$ & 78 & 30,6 \\
\hline & 41 yaş ve üzeri & 52 & 20,4 \\
\hline \multirow{3}{*}{$\begin{array}{l}\text { Kurumda çalışma } \\
\text { süresi }\end{array}$} & 5 y1ldan az & 105 & 41,2 \\
\hline & 5-10 y1l & 80 & 31,4 \\
\hline & 11 y1l ve üzeri & 70 & 27,5 \\
\hline Toplam & & 255 & 100,0 \\
\hline
\end{tabular}

Tablo 2'de araştırmaya katılanların sosyo-demografik özellikleri incelendiğinde; katılımcıların \%49'unun 20-30 yaş aralığında, \%65,1'inin kadın, \%53,7'sinin evli, \%51,4'ünün üniversite mezunu, \%41,2’sinin çalıştı̆̆ kurumda görev süresinin ilk beş y1lı içerisinde, \%58'inin tıbbi sekreter ve hasta danışmanı olduğu saptanmıştır.

Tablo 3: Araştırma Ölçekleri Faktörleri Ortalamalarının Dağılımı

\begin{tabular}{lcc}
\hline Eğitim ve Gelişimin Boyutları & Ort. & Std. sapma \\
\hline Öğrenme Motivasyonu & 3,8125 &, 71711 \\
\hline Bireysel Kazançlar & 3,7333 &, 82258 \\
\hline Algılanan Amir Desteği & 3,6451 &, 96418 \\
\hline Algılanan Çalışma Arkadaşları Desteği & 3,3980 &, 83678 \\
\hline Algılanan Eğitim Olanakları & 3,2369 &, 69399 \\
\hline Kariyer Beklentileri & 3,0235 & 1,17279 \\
\hline Toplam Eğitim ve Geliştirme & 3,4749 &, 61421 \\
\hline İş Tatmini & 3,3937 &, 78781 \\
\hline
\end{tabular}

Tablo 3'te katılımcıların verdikleri cevaplar incelendiğinde; toplam eğitim ve geliştirme düzeyinin 3,3937 (Min.1Max.5), çalışanların genel memnuniyet düzeyinin 3,3937 (min.1- max.5) olduğu saptanmıştır. Ayrıca katılımcıların eğitim ve gelişim faaliyetlerinden en çok "öğrenme motivasyonu" ve "bireysel kazançlar", en az "kariyer beklentileri" ve "algılanan eğitim olanakları" boyutlarına katıldıkları da görülmektedir.

Yapılan normal dağılım analizi sonucunda iş tatmini ölçeğinde verilerin normal dağıldığı $(p>0,005)$; eğitim ve geliştirme ölçeğinde ise verilerin normal dağılmadığı belirlenmiştir $(\mathrm{p}<$ 0.05). Normal dağılımın diğer varsayımları olan ortalama-medyanın birbirine yakınlığ basıklık (kurtosis) ve çarpıklığın (skewnes) -2, +2 arasında olması gerekliliği açısından incelendiğinde; değişkene göre bu değerlerin de normal dağılıma uyduğu belirlenmiştir. $\mathrm{Bu}$ sebeple çalışmada parametrik testlerin kullanılmasına karar verilmiştir.

Tablo 4: Katılımcıların Eğitim ve Geliştirme Faaliyetleri Algısı ve İş Tatmini Düzeyinin Sosyo-Demografik Değişkenlere Göre Farklılık Gösterip Göstermediğine İlişkin Student T Testi Analizi 


\begin{tabular}{|c|c|c|c|c|c|c|c|}
\hline & & Değişken Adı & $\mathbf{N}$ & Ort. & Std. Sapma & $\mathbf{t}$ & $\mathbf{p}$ \\
\hline \multirow{6}{*}{ Hastane Türü } & \multirow{2}{*}{ Algılanan Amir Desteği } & Özel hastane & 105 & 3,8381 & ,92116 & \multirow{2}{*}{2,734} & \multirow{2}{*}{$0,007 * *$} \\
\hline & & Kamu hastanesi & 150 & 3,5100 & ,97359 & & \\
\hline & \multirow{2}{*}{ Toplam Eğitim Geliştirme } & Özel hastane & 105 & 3,5386 & ,50737 & \multirow{2}{*}{1,387} & \multirow{2}{*}{0,167} \\
\hline & & Kamu hastanesi & 150 & 3,4303 & ,67718 & & \\
\hline & \multirow{2}{*}{ İş Tatmini } & Özel hastane & 105 & 3,4190 & 81315 & \multirow{2}{*}{$-0,429$} & \multirow{2}{*}{0,668} \\
\hline & & Kamu hastanesi & 150 & 3,3760 & ,77183 & & \\
\hline \multirow{4}{*}{ Cinsiyet } & \multirow{2}{*}{ Toplam Eğitim Geliştirme } & Kadın & 166 & 3,4548 & ,59919 & \multirow{2}{*}{$--0,712$} & \multirow{2}{*}{0,477} \\
\hline & & Erkek & 89 & 3,5124 & ,64307 & & \\
\hline & \multirow{2}{*}{ İş Tatmini } & Kadın & 166 & 3,3117 & ,79867 & \multirow{2}{*}{$--2,334$} & \multirow{2}{*}{0,21} \\
\hline & & Erkek & 89 & 3,5466 &, 74772 & & \\
\hline \multirow{4}{*}{ Meslek türü } & \multirow{2}{*}{ Toplam Eğitim Geliştirme } & Sağlık profesyonelleri & 107 & 3,4704 &, 63012 & \multirow{2}{*}{$-0,099$} & \multirow{2}{*}{0,921} \\
\hline & & Tibbı sekreter/ hasta danışmanı & 148 & 3,4782 & ,60459 & & \\
\hline & \multirow{2}{*}{ İş Tatmini } & Sağlık profesyonelleri & 107 & 3,5131 &, 77874 & \multirow{2}{*}{2,073} & \multirow{2}{*}{$0,039 *$} \\
\hline & & Tibbı sekreter/ hasta danışmanı & 148 & 3,3074 & ,78566 & & \\
\hline
\end{tabular}

$* \mathrm{p}<0,05 ; * * \mathrm{p}<0,01$

Tablo 4'de bazı sosyo-demografik değişkenlere göre araştırma ölçeklerine verilen cevapların Student t testi analizi (iki ortalama arasındaki farkın önemliliğinin sınanması) incelendiğinde istatistiksel olarak anlamlı düzeyde;

- Özel hastane çalışanlarının amir desteği algı düzeyinin kamu hastane çalışanlarına göre daha fazla olduğu $(\mathrm{p}<0,01)$;

- Erkek çalışanların kadın çalışanlara göre eğitim olanakları algılarının daha fazla $(\mathrm{p}<0,05)$ saptanmıştır.
- Toplam eğitim ve geliştirme açısından cinsiyet değişkenine göre anlamlı bir farklılığın olmadığ (p>0,05);

- İş tatmini açısından erkek çalışanların kadın çalışanlara göre daha fazla memnun oldukları $(\mathrm{p}<0,05)$;

- İş tatmini açısından sağlık profesyonellerinin (hekim, hemşire, sağlık teknikeri), tıbbi sekreter ve hasta danışmanına göre daha fazla memnun oldukları $(\mathrm{p}<0,05)$ saptamıştır.

Tablo 5: Katılımcıların Eğitim ve Geliştirme Faaliyetleri Algısı ve İş Tatmini Düzeyinin Sosyo-Demografik Değişkenlere Göre Farklılık Gösterip Göstermediğine İlişkin ANOVA (Varyans) Analizi

\begin{tabular}{|c|c|c|c|c|c|c|c|}
\hline & & Değişken Adı & $\mathbf{N}$ & Ort. & Std. Sapma & $\mathbf{F}$ & $\mathbf{p}$ \\
\hline \multirow{9}{*}{ Yaş Değişkeni } & \multirow{3}{*}{ Algılanan Amir Desteği } & $20-30$ & 125 & 3,8120 & ,84401 & \multirow{3}{*}{4,727} & \multirow{3}{*}{$0,010^{* *}$} \\
\hline & & $31-40$ & 78 & 3,3910 & 1,07404 & & \\
\hline & & 41 yaş ve üzeri & 52 & 3,6250 & ,99447 & & \\
\hline & \multirow{3}{*}{ Toplam Eğitim Geliştirme } & $20-30$ & 125 & 3,5565 & ,53158 & \multirow{3}{*}{4,196} & \multirow{3}{*}{$0,016^{*}$} \\
\hline & & $31-40$ & 78 & 3,3100 & ,57582 & & \\
\hline & & 41 yaş ve üzeri & 52 & 3,5260 & ,79415 & & \\
\hline & \multirow{3}{*}{ İş Tatmini } & $20-30$ & 125 & 3,4096 & ,76350 & \multirow{3}{*}{0,821} & \multirow{3}{*}{0,441} \\
\hline & & $31-40$ & 78 & 3,3083 & ,78125 & & \\
\hline & & 41 yaş ve üzeri & 52 & 3,4837 & ,85570 & & \\
\hline \multirow{9}{*}{ Eğitim Durumu } & \multirow{3}{*}{ Algılanan Amir Desteği } & Lise & 90 & 3,8667 & ,85722 & \multirow{3}{*}{3,865} & \multirow{3}{*}{$0,022 *$} \\
\hline & & Üniversite & 131 & 3,5420 & 99041 & & \\
\hline & & Lisansüstü & 34 & 3,4559 & 1,04713 & & \\
\hline & \multirow{3}{*}{ Toplam Eğitim Geliştirme } & Lise & 90 & 3,5939 & ,63983 & \multirow{3}{*}{2,704} & \multirow{3}{*}{0,069} \\
\hline & & Üniversite & 131 & 3,4017 & ,57459 & & \\
\hline & & Lisansüstü & 34 & 3,4422 & 66183 & & \\
\hline & \multirow{3}{*}{ İş Tatmini } & Lise & 90 & 3,5639 & ,71857 & \multirow{3}{*}{3,308} & \multirow{3}{*}{$0,038^{*}$} \\
\hline & & Üniversite & 131 & 3,2981 & ,78900 & & \\
\hline & & Lisansüstü & 34 & 3,3118 & 90000 & & \\
\hline
\end{tabular}

${ }^{*} \mathrm{p}<0,05 ; * * \mathrm{p}<0,01$

Tablo 5'de bazı sosyo-demografik değişkenlere göre araştırma ölçeklerine verilen cevapların varyans analizi incelendiğinde;

- 20-30 yaş aralığındaki çalışanların 31-40 yaş aralığındaki çalışanlara göre amir desteği algılarının $(p<0,01)$ ve toplam eğitim ve geliştirme algılarının $(p<0,05)$ daha fazla olduğu
- Lise mezunu çalışanların lisansüstü mezunu çalışanlara göre amir desteği algılarının daha fazla $(\mathrm{p}<0,05)$ olduğu saptanmıştır.

- Ayrıca lise mezunu çalışanların iş tatminlerinin üniversite mezunlarına göre daha yüksek olduğu da görülmektedir $(\mathrm{p}<0,05)$.

Bu sonuçlara göre $\mathrm{H}_{2}$ ve $\mathrm{H}_{3}$ hipotezleri kabul edilmiştir. 
Tablo 6: Katılımcıların Eğitim ve Geliştirme Faaliyetleri Algısı ve İş Tatmini Düzeyi Arasındaki İlişkiye İlişkin Korelasyon Analizi

\begin{tabular}{|c|c|c|c|c|c|c|c|}
\hline & $\begin{array}{l}\text { Algılanan } \\
\text { Eğitim } \\
\text { Olanakları }\end{array}$ & $\begin{array}{l}\text { Algılanan } \\
\text { Amir } \\
\text { Desteği }\end{array}$ & $\begin{array}{l}\text { Algılanan } \\
\text { Çalışma } \\
\text { Arkadaşları } \\
\text { Desteği }\end{array}$ & $\begin{array}{c}\text { Öğrenme } \\
\text { Motivasyonu }\end{array}$ & $\begin{array}{c}\text { Bireysel } \\
\text { Kazançlar }\end{array}$ & $\begin{array}{c}\text { Kariyer } \\
\text { Beklentileri }\end{array}$ & $\begin{array}{l}\text { Toplam Eğitim- } \\
\text { Geliştirme }\end{array}$ \\
\hline İș Tatmini &, $482^{* *}$ &, $511^{* *}$ & $230^{* *}$ &, $564^{* *}$ &, $520^{* *}$ &, $562^{* * *}$ &, $681^{* *}$ \\
\hline
\end{tabular}

Korelasyon katsayısını yorumlamada genel olarak; 0,000,30 arası düşük düzeyde, $0,30-0,70$ arası orta düzeyde 0,70 1,00 arası yüksek düzeyde bir ilişkinin var olduğu söylenebilir (Büyüköztürk, 2002). Tablo 6'da katılımcıların eğitim ve geliştirme faaliyetleri ve iş tatmini algıları arasındaki korelasyon analizi sonuçları incelendiğinde; sağlık çalışanların kariyer yönetimi kapsamında eğitim ve geliştirme algıları ile iş tatmini arasında pozitif yönlü orta düzey $(\mathrm{r}=0,681)$ korelasyon saptanmıştır $(\mathrm{p}<0,01)$. Bu durum, sağlık çalışanlarının kariyer yönetimi kapsamında

Tablo 7. Katılımcıların Eğitim ve Geliştirme Faaliyetleri Algısının İş Tatmini Düzeyi Üzerindeki Etkisine İlişkin Regresyon Analizi

\begin{tabular}{lcccccc}
\hline & R & R2 & Düzeltilmiş R2 & F & 及 & $\begin{array}{c}\text { Anlamlılık } \\
\text { (ANOVA) }\end{array}$ \\
\hline Algılanan Eğitim Olanakları & 0,482 & 0,232 & 0,229 & 76,575 & 0,482 & 0,000 \\
\hline Algılanan Amir Desteği & 0,511 & 0,261 & 0,258 & 89,266 & 0,511 & 0,000 \\
\hline Algılanan Çalışma Arkadaşları Desteği & 0,230 & 0,053 & 0,049 & $14,0,93$ & 0,230 & 0,000 \\
\hline Öğrenme Motivasyonu & 0,564 & 0,319 & 0,316 & 118,244 & 0,564 & 0,000 \\
\hline Bireysel Kazançlar & 0,520 & 0,270 & 0,268 & 93,781 & 0,520 & 0,000 \\
\hline Kariyer Beklentileri & 0,562 & 0,315 & 0,313 & 116,534 & 0,562 & 0,000 \\
\hline Toplam Eğitim- Geliştirme & 0,681 & 0,464 & 0,462 & 218,979 & 0,681 & 0,000 \\
\hline
\end{tabular}

Bağımlı Değişken: İş Tatmini

Bağımsız Değişken: Eğitim ve geliştirme faaliyetler

Tablo 7'deki regresyon analizi sonuçlarına göre işyerinde eğitim ve geliştirme faaliyetlerinin çalışanların iş tatmini üzerinde pozitif ve anlamlı bir etkiye sahip olduğu görülmektedir $(\beta=-0,681 \mathrm{p}<0,001)$. R2 değerinin 0,464 olması, eğitim ve geliştirme faaliyetlerinin iş tatminin \%46,4'lük kısmını açıkladığını göstermektedir. Bu sonuca göre $\mathrm{H}_{1}$ hipotezi kabul edilmiştir.

\section{Sonuç ve Öneriler}

Kariyer yönetimi kapsamında eğitim ve geliştirme faaliyetlerinin çalışanların memnuniyeti üzerine etkisini ölçmek amaciyla Antalya 2'si özel 2'si kamu olmak üzere 4 hastanenin 255 sağlık çalışanı üzerinde yapılan bu çalışmada; eğitim ve geliştirme faaliyetlerinin iş tatmini arasında orta düzey pozitif bir ilişki olduğu ve eğitim ve geliştirme faaliyetlerinin iş tatmini üzerinde olumlu bir etkisinin olduğu saptanmıştır.

Katılımcıların verdikleri cevaplar incelendiğinde; toplam eğitim ve geliştirme düzeyinin 3,3937 (Min.1-Max.5), çalışanların genel memnuniyet düzeyinin 3,3937 (min.1max.5) olduğu saptanmıştır. Ayrıca katılımcıların eğitim ve gelişim faaliyetlerinden en çok "öğrenme motivasyonu" ve "bireysel kazançlar", en az "kariyer beklentileri" ve "algılanan eğitim olanakları" boyutlarına katıldıkları da görülmektedir.

Diğer taraftan, sosyo-demografik açıdan, eğitim geliştirme faaliyetlerine yönelik olumlu algılarının iş tatminini olumlu yönde etkilediğini ortaya koymaktadır.

Ayrıca çalışan performansı ile eğitim ve geliştirme faaliyetlerinin boyutları arasında en düşük korelasyon "algılanan amir desteği” ( $(\mathrm{r}=0,230)$ pozitif yönlü düşük düzeyde ilişki; en yüksek korelasyon "Öğrenme Motivasyonu” $(r=0,564)$ pozitif yönlü orta düzeyde ilişki saptanmıştır.

- Özel hastane çalışanlarının amir desteği algı düzeyinin kamu hastane çalışanlarına göre daha fazla olduğu $(\mathrm{p}<0,01)$;

- Erkek çalışanların kadın çalışanlara göre eğitim olanakları algılarının daha fazla olduğu $(\mathrm{p}<0,05)$, toplam eğitim ve geliştirme açısından cinsiyet değişkenine göre anlamlı bir farklılığın olmadığı $(\mathrm{p}>0,05)$;

- 20-30 yaş aralığındaki çalışanların 31-40 yaş aralığındaki çalışanlara göre amir desteği algılarının $(p<0,01)$ ve toplam eğitim ve geliştirme algılarının $(\mathrm{p}<0,05)$ daha fazla olduğu;

- Lise mezunu çalışanların lisansüstü mezunu çalışanlara göre amir desteği algılarının daha fazla olduğu $(\mathrm{p}<0,05)$;

- İş tatmini açısından erkek çalışanların kadın çalışanlara göre daha fazla memnun olduğu $(\mathrm{p}<0,05)$; lise mezunu çalışanların iş tatminlerinin üniversite mezunlarına göre daha yüksek olduğu $(p<0,05)$; sağlık profesyonellerinin (hekim, hemşire, sağlık teknikeri), tıbbi sekreter ve hasta danışmanına göre daha fazla memnun olduğu $(\mathrm{p}<0,05)$ saptanmıştır.

Kariyer yönetimi ve bu yönetimin içerisinde eğitim ve geliştirme faaliyetleri hem çalışanlar hem de işletmeler açısından üzerinde durulması gereken önemli konular arasında yer almaktadır. Geçmişte yapılan çalışmalar ve bu araştırma, işletmelerde eğitim ve geliştirme faaliyetlerinin çalışanların memnuniyetleri üzerinde olumlu etkisi 
olduğunu göstermektedir. Bu durum, sağlık örneklemi üzerinde bu çalışmayla test edilmiştir.

Sağlık kurumları içerisinde birçok farklı meslek grubu ekip çalışmasına dayalı yoğun, stresli ve hayati bir hizmeti sunmaya çalışmaktadırlar. $\mathrm{Bu}$ meslek grupları kariyer anlamında örgütsel hedeflerini yanısıra bireysel kariyer beklentisi içerisindedirler. Ayrıca sağlık sektöründe tıbbi, teknolojik ve idari alanda birçok değişikliğin sıklıkla olduğu düşünülürse sağlık çalışanlarının eğitim ve gelişim ihtiyacı hem örgütsel hedeflerin gerçekleştirilmesi hem de bireysel kariyer açısından son derece önemlidir.

Sonuç olarak, hem yapılan literatür çalışmaları hem de bu araştırma, kariyer yönetimi kapsamında eğitim geliştirme faaliyetlerinin iş tatmini üzerinde olumlu yönde etkisinin olduğunu göstermektedir. İşletmelerdeki eğitim ve geliştirme faaliyetlerinin etkili ve verimli olması için hem işletme hem de çalışan açısından kazan-kazan temelli yürütülmesi uygun olacaktır. Bu açıdan hayati, ertelenemez ve tolere edilemez bir hizmet türünü sunan sağlık çalışanlarının memnuniyetlerinin sağlanmasında, onlara tanınan eğitim ve geliştirme imkânlarının artırılması son derece önemli olacaktır.

İşletmelerin eğitim ve geliştirme faaliyetlerinde, ders, konferanslar ve vaka çalışmaları gibi eğitim ve öğretim araçlar kullanılırken yeni teknolojilerden (bilgisayar/simüle oyunlar, rol oynama ve ses/görsel araçlar gibi) yararlanmaları, bu faaliyetlerin daha etkili hale getirilmesine katkı sağlayacaktır.

\section{Kaynakça}

Abdulraheem Salah, M. R. (2016). The Impact of Training and Development on Employees Performance and Productivity. International Journal of Management Sciences and Business Research, 5(7).

Allencomm, (2019, 19 Eylül). What is Employee Training And Development?, Inc., Erişim adresi: https://www.allencomm.com/what-is-employeetraining-development/

Alpar, R. (2000). Spor Bilimlerinde Uygulamalı İstatistik. Ankara: GSGM Yayınları

Altınışık, İ. ve Peker, H.S. (2012). Eğitimin Ekonomik Kalkınmaya Etkisi, Sosyoteknik Sosyal ve Teknik Araştırmalar Dergisi, Yı1:2 Sayı:4

Anadolu Sözlük (2019, 19 Eylül). Erişim adresi: http://www.anadolusozluk.org/t.php?b=10540

Armstrong, M. (2008). Strategic Human Resource Management A Guide to Action, + th Edition, ebook, www.koganpage.com/strategichrm, 1-246.

Aslan, G. (2012). İnsan Kaynakları Yönetiminde İşe Alma ve Eğitimin Kariyer Yönetimi İle İlişkisi, Bir Şirketin Kariyer Yönetimi Üzerine İnceleme. Yayınlanmamış YL Tezi. TC Beykent Üniversitesi, İstanbul.

Ball, B., and Jordan, M. (1997). An open-learning approach to career management and guidance. British Journal of Guidance and Counselling, 25(4), 507-516.
Barutçugil, İ. (2004). Stratejik İnsan Kaynakları Yönetimi. Kariyer Yayınları.

Bayrakdar: (2011). “Avrupa Birliği Mesleki Eğitim Programlarında Girişimcilik Eğitimlerinin Ekonomik Kalkınmadaki Önemi”, C.Ü. İktisadi ve İdari Bilimler Dergisi, Cilt 12, Sayı1, Sivas

Bayraktaroğlu, Serkan (2006). İnsan Kaynakları Yönetimi. Sakarya: Gazi Kitabevi, Ankara.

Brown, Duane (2002). Career Choice And Development, John Wiley \& Sons.

Büyüköztürk, Ş. (2002). Sosyal Bilimler için Veri Analizi El Kitabı. Ankara: Pegem Yayıncılık (2.Bask1).

Erdil, O. ve Öztutku, H. (2013). (Editör) İnsan Kaynakları Yönetimi, Lisans yayınları.

Ergün, M. (2011). "Eğitim ve Kalkınma". 3.Sosyal Bilimler Sempozyumu. Bölgesel Kalkınmada Eğitimin Rolü, Dicle Üniversitesi Sosyal Araştırmalar Merkezi, Diyarbakır.

Fındıkçı, İ. (2018). İnsan kaynakları yönetimi. Alfa Basım Yayım Dă̆ıtım.

Geylan, Ramazan (2004). (Editör) İnsan Kaynakları Yönetimi, AÖF yayınları.

Inc. (2019, 19 Eylül). Training and Development Erişim adresi: https://www.inc.com/encyclopedia/ trainingand-development.html

Izgar, H. (2012). Endüstri ve Örgüt Psikolojisi (3. Bask1). Konya: Ĕgitim Yayınevi.

Jaiswal, Pooja, Archana Chandra, Jaiswal.Archana. « Employee Satisfaction Towards Training And Development Practices In Bharat Pumps And Compressor Limited Naini Allahabad.» Ms Pooja Jaiswal Research Scholar, Sam Higginbottom Institute Of Agriculture Technology And Sciences (Shiats) Allahabad, Irjmst, Vol 5, Issue 10, Year 2014, 25-39.

Kahraman, H. B. ve Find1klı, M. A. (2017). Kariyer Yönetimi Kapsamında Eğitim ve Geliştirme Faaliyetlerine Yönelik Algıların Çalışan Memnuniyeti Üzerindeki Etkileri. Beykent Üniversitesi Sosyal Bilimler Dergisi, 11(2), 51-68.

Keser, Aşkın (2012) Çalışma Psikolojisi, 3.Basım, Ekin Yayınevi, Bursa.

Kozak, A. Meryem (2001). Konaklama İşletmelerinde Kariyer Planlaması. Eskişehir: Anadolu Üniversitesi Basımevi.

Low, L (1998) Human resource development in the AsiaPacific. Asian-Pacific Economic Literature, 12 (1): pp. 27-40.

Nadeak, B. and Purba, J. T. (2014). Applied Management Strategy on Human Capital in Higher Education for Faculty Development in the Dynamic Service Industry: A case study. Journal of Content Business in Today's Industry, 1, 57-66. 
Noe, R. A. (1996). Is career management related to employee development and performance?. Journal of organizational behavior, 17(2), 119-133.

Öge, H. S. (2016). İnsan Kaynakları Yönetimi, Eğitim Akademi Yayınları. 8. Baskı, Konya.

Özsoy, C. (2007). Türkiye'de Mesleki Eğitim ve Teknik Eğitimin İktisadi Kalkınmadaki Yeri ve Önemi, Anadolu Üniversitesi Yayınları; No.780, Eskişehir

Sadullah, Ö., Uyargil, C., Acar, A., Özçelik, A., Dündar, G., Ataay, I. D. ve Tüzüner, L. (2013). İnsan Kaynakları Yönetimi. Beta Basım Yayım, İstanbul.

Schmidt, S. W. (2009). Employee demographics and job training satisfaction: the relationship between dimensions of diversity and satisfaction with job training. Human Resource Development International, 12(3), 297-312.

Soysal, A. ve Kılınç, E. (2016). İşletmelerde Stratejik İnsan Kaynakları Yönetimi Sürecinde Performans Değerlendirme ve Kariyer Yönetimi Uygulamaları. Sosyal Ekonomik Araştırmalar Dergisi, (31), 325-347.

Şener, M. (2009) Hizmet İçi Eğitimin SınıfÖğretmenlerinin Motivasyon Düzeyine Etkisi, Eğitim Bilimleri Enstitüsü, Marmara Üniversitesi, Yüksek Lisans Tezi, İstanbul.
Şimşek, M., Çelik, A. ve Akatay, A. (2016). İnsan kaynakları yönetimi ve kariyer uygulamaları, 3. Baskı, Eğitim yayınları, Konya.

Şimşek, Ş., Çelik, A. ve Akgemci, T. (2015). Davranış Bilimlerine Giriş ve Örgütsel Davranış, 9. Baskı, Ĕ̈itim Kitabevi, Ankara.

Şimşek, Ş.M. (2013) İnsan Kaynakları Yönetimi (1.Baskı) Saray matbaacılık, Ankara.

Tunçalp, K. (2013). Mesleki Eğitimin Ulusal-Uluslararası Rekabete Açılması ve Sertifikasyonu, Akademik Araştırma Projeleri, İstanbul

Universal Class, (2019, 15 Eylül). Personal Development and Career Management, Erişim adresi: https://www.universalclass.com/articles/business/pe rsonal-development-and-career-management.htm

Weiers, R. (2008). Introduction to Business Statistics. South Western Cenage Learning.

Yapıcı, M. (2003). Yaygın Eğitim, Üniversite ve Toplum, Cilt 3, Sayı 1

Your Training Edge, (2019, 19 Eylül). How Can Training Help in Increasing Employee Productivity? Erişim adresi: https://www.yourtrainingedge.com/how-cantraining-help-in-increasing-employee-productivity/ 